\title{
Radical Craft: Exhibiting Homelands in Rochester, New York
}

\author{
A. JOAN SAAB
}

This article looks at the Homelands Exhibition in Rochester, New York which took place in the spring of 1920. Placing the craft objects on display, as well as their makers and their creative labor, into a larger constellation of local and national history, I focus on how the material culture of the show acted simultaneously as a stand-in and an extensions of their makers, to trouble the boundaries between author and reader, art and work, producer and spectator, the quotidian and the exceptional, and ultimately to question what it meant to be American at this particular moment in time.

In April I920, the Memorial Art Gallery in Rochester, NY collaborated with the Rochester Chamber of Commerce, the Board of Education, and the city administration in organizing a ten-day exposition celebrating the art and culture of immigrant citizens. Called the "Homelands Exhibition," the event followed similar programs in Buffalo and Albany and aimed "to give foreign born residents of the city a correct conception of the motives of the Chamber in conducting Americanization work." Held from io-19 April, the Rochester show consisted of four thousand exhibits of ethnic arts and crafts and included objects and participants from at least seventeen countries. ${ }^{\mathrm{r}}$ Each ethnic group was clearly identified and each display was accompanied by members of the group who either demonstrated how the works were made or explained the process to the steady stream of spectators. Admission was free

Department of Art History, University of Rochester. Email: joan.saab@rochester.edu.

${ }^{I}$ Memorial Art Gallery Archives, Homelands Folder, n.p., emphasis mine. According to the planning documents, the countries represented in the Memorial Art Gallery show were Norway, Russia, Holland, the Near East, Denmark, the Far East, Poland, Portugal, Ukraine, Belgium, Sweden, Spain, Brittany, and Italy. There were also Jewish and "Cosmopolitan" booths and nightly performances by Native Americans. Unfortunately, I have found no material that outlines the selection process so there is no way to know how the committee decided who exactly to include, or exclude, from the exhibition. 
and over 160,000 people (including 30,000 schoolchildren) attended. There were also a variety of performances by different ethnic groups on a central stage throughout the day and evening for each day of the show's ten-day run. More than two thousand people participated in the twenty-four performances and "all performers were of foreign birth or parentage," except "the original Americans" who staged the opening scene each night.

Originally intended to be held on-site at the newly established Memorial Art Gallery (MAG), organizers quickly realized that there was not enough room for such an ambitious project on the museum's grounds and moved it to the much larger Building 4 in nearby Exposition Park, where "every inch of space [was] taken." 2 The show was funded in large part by the liberal Russell Sage Foundation, whose founding mission was "the improvement of social and living conditions in the United States of America," with a focus on "the larger and more difficult problems" that concerned the urban, often immigrant poor and elderly; thus its emphasis on "correct" conceptions of Americanization is significant. ${ }^{3}$

By 1920, federal laws such as the 1917 Espionage Act and the 1918 Sedition Act, as well as the aggressive activities of Attorney General Mitchell Palmer and his special assistant J. Edgar Hoover during the I919 "Red Scare," had begun to severely limit the rights of recent immigrants in the name of national security. ${ }^{4}$ Moreover, privately funded endeavors such as the Lusk Committee joined with other government agencies to forcibly crack down on immigrant communities across New York State, including communities in Rochester, Albany, and Buffalo.5 Rather than target the foreign-born as possible subversives or dangerous citizens, however, the Homelands shows instead highlighted what Jane Addams called their "immigrant gifts," which for Addams consisted of "their handicrafts and occupations, their traditions, their folk songs and folklore, the beautiful stories which every immigrant colony is ready to tell." ${ }^{\prime 6} \mathrm{By}$

2 "Crowds See First Show at Homelands," Rochester Herald, i I April i $920,13$.

${ }^{3}$ In her letter of bequest establishing the Russell Sage Fund, Margaret Olivia Sage explained, "The scope of the Foundation is not only national but is broad. It should, however, preferably not undertake to do that which is now being done or is likely to be effectively done by other individuals or by other agencies. It should be its aim to take up the larger and more difficult problems, and to take them up so far as possible in such a manner as to secure co-operation and aid in their solution." Margaret Olivia Sage letter dated I 9 April 1907, reprinted at www.russellsage.org/about/history.

${ }^{4}$ See www.digitalhistory.uh.edu/disp_textbook.cfm? $\operatorname{smtID}=2 \& p s i d=3479$, accessed 7 July 2015 .

${ }^{5}$ For more on the Lusk Committee see www.albany.edu/faculty/gz $580 /$ his I o / luskguid. html.

${ }^{6}$ The term "immigrant gifts" is Jane Addams's. She first used it in a speech to the National Educational Association in 1908. Jane Addams cited in Rivka Shpak Lissak, Pluralism and Progressives: Hull House and the New Immigrants 1890-19I9 (Chicago: The University of 
showcasing folk art and performance, the Homelands shows put both craft objects and craft makers on display, seamlessly equating material culture with its creators and tying both to their country of origin, or "Homeland."

This article looks at the Rochester Homelands Exhibition to trace what anthropologist Arjun Appadurai calls the "social life" of the things and people on display in Rochester, New York in the spring of $1920 .{ }^{8}$ Placing these craft objects, as well as their makers and their creative labor, into a larger constellation of local and national history underscores what Aiwah Ong has identified as the "dual process" of cultural citizenship as "self-making and being-made." Focussing on the material culture of the show, as simultaneously stand-in and extension of its makers, troubles the boundaries between art and work and producer and spectator, and ultimately, I would argue, questions what it meant to be American at this particular moment in time.

The objects chosen for inclusion in the show were "picked with care" by a team from the museum. George Herdle, the first director of MAG and chairman of the Exhibit Committee, sent letters to local community leaders, immigrant groups, settlement houses, and churches across the city to drum up support and material for the exhibition. Together they identified distinct national committees and held meetings for specific ethnic groups to encourage participation and representation in the show. Much like nineteenth-century ladies' fancy fairs and charity bazaars, the displays in the Homelands Exhibition contained a cornucopia of exotic goods, simultaneously marking the objects on display as both "foreign" and safe. ${ }^{\circ}$ According to a report by the Russell Sage Foundation, "the unique and distinguishing feature of these exhibitions was the conscious appeal to the sense of the beautiful. The arts and crafts were chosen because they combined beauty with human interest." But, the planners stressed, "this aesthetic appeal" was not merely decorative; rather, it encapsulated one of the guiding principles of the event, "for when

Chicago Press, 1989), 55. Addams further elaborated on the idea and its relationship to education in her book The Spirit of Youth and the City Streets (New York: Macmillan, 1909).

7 The emergence of folk art as a category is beyond the scope of this article. For more on the role of folk art in Americanization exercises see Sarah Deutsch, No Separate Refuge: Culture, Class and Gender on an Anglo-Hispanic Frontier 1880-1940 (New York: Oxford University Press, 1987); and Mina Carson, Settlement Folk: Social Thought and the American Settlement Movement 1885-1930 (Chicago: The University of Chicago Press, 1990).

8 Arjun Appadurai, The Social Life of Things (Cambridge: Cambridge University Press, 1986).

9 Aihwah Ong, "Cultural Citizenship as Subject Making," Current Anthropology, 37, 4 (Dec. 1996), 737-62, 737 .

10 For more on Ladies Fairs see Kathleen McCarthy, Women's Culture: American Philanthropy and Art 1830-1930 (Chicago: The University of Chicago Press, 1993); and Beverly Gordon, "Playing at Being Powerless: New England Ladies Fairs, I 830-1930," Massachusetts Review, Inc., Spring 1986, 144-60. 
minds and hands are used to fashion beautiful objects an alphabet is created which may be understood by all people everywhere."

The idea of a legible alphabet of craft and performance communicating across language, religion, and ethnicity aimed to foster an understanding of difference as central to American identity since, ultimately, planners argued that to "take part [in the show] is the essence of democracy." I Following contemporary thinkers such as Horace Kallen and Randolph Bourne, who wrote extensively on the links between cultural pluralism and American democracy, the rhetoric of the planners stressed inclusion and choice. ${ }^{12}$ Participants, they argued, "brought from their homelands to the land of their choice the traditions, the arts, the handicrafts, the music, the dances, the games, and the ardor, the love of beauty, the instinct for happiness, the zest for life of strong, natural, simple people." I3 By including representative individuals from different ethnic groups in their exhibits, the Homelands' planners put on display not just an array of beautiful handmade goods but also the "foreign born" themselves, as both objects and artists. By highlighting the labor that went into making the works on display, through performance and demonstrations, the foreignborn, and by extension the things they made, functioned as ethnographic objects as well as sites for performing a range of individual autobiographies and collective national histories - all in the process of being Americanized. These narratives of simultaneously being ethnic and becoming American were thus authored and read by those included in the exhibits as well as by visitors to the show, which included the "native born" as well as the other "foreign born" participants in the exhibition.

In many ways, with its emphasis on tolerance towards difference as achieved through performance and craft work, the Rochester Homelands Exhibition exemplifies the Progressive-era goal of creating an informed democratic citizenry through ways of seeing and doing. This was perhaps best articulated by turn-of-the-century reformers such as John Dewey and Jane Addams who, following the work of British Arts and Crafts advocates William Morris and John Ruskin, encouraged experience-based learning as a means of integrating

${ }^{1}$ See http://mag.rochester.edu/plugins/acrobat/history/homelands/DocsFromMAGArchives2.pdf. See also Allen H. Eaton, Immigrant Gifts to American Life: Some Experiments in Appreciation of the Contributions of Our Foreign-Born Citizens to American Culture (New York: Russell Sage Foundation, I932), 3 I.

12 Horace Kallen, "Democracy versus the Melting-Pot: A Study of American Nationality: Part I and Part II," The Nation, 8 Feb. 1915, 190-94, and 25 Feb. 217-20. Randolph Bourne, "Trans-national America," Atlantic Monthly, July 1916, repr. in Randolph Bourne: The Radical Will, Selected Writings I9II-19I8, ed. Olaf Hansen (Berkeley: University of California Press, 1992).

${ }^{13}$ See http://mag.rochester.edu/plugins/acrobat/history/homelands/DocsFromMAGArchives2.pdf; and Eaton, $3 \mathrm{I}$. 
cultural difference into a democratic society. ${ }^{14}$ Dewey, Addams and their contemporaries in the Settlement House and Progressive education movements repeatedly stressed the importance of artistic labor as a form of social engagement, particularly for immigrant and working-class communities. ${ }^{\text {Is }}$

Historians usually define the Progressive Era as dating from the 1890 s to the 1920s. ${ }^{16} \mathrm{~A}$ time of intense activism and reform, Progressivism was in large part a response to the immense changes brought about by increased industrialization, immigration, and urbanization and the resulting reallocation of wealth and power in the United States at the turn of the last century. It was led in large part by middle-class professionals - doctors, lawyers, teachers, nurses who despite their differences were united in a belief in progress and a sense of optimism about the future and their ability to shape it. As Gary Gerstle has argued in his landmark essay "The Protean Character of American Liberalism," for most Progressives "the reinvigoration of democracy depended upon moral regeneration as much as it did on economic reform." ${ }^{17}$ Although the precise contours of Progressivism are beyond the scope of this piece, following historians Philip Ethington and Sarah Wilson I am treating the

${ }^{14}$ For more on the influence of John Ruskin and William Morris in the United States see Eileen Boris, Art and Labor: Ruskin, Morris and the Craftsman Idea in America (Philadelphia: University Press, 1988). For more on Dewey and Addams and Settlement House philosophy see Shannon Jackson, Lines of Activity: Performance, Historiography and Hull-House Domesticity (Ann Arbor: University of Michigan Press, 2001).

is For more on John Dewey and Americanization efforts see Robert Westbrook, John Dewey and American Democracy (Ithaca, NY: Cornell University Press, I 993), 2 I 2-I 3.

${ }^{16}$ Progressivism's constituents included temperance reformers, muck-raking journalists, and radical labor leaders, and its activities ranged from the legal policies of what historian William Chafe has called the "big P Progressivism" of politicians such as Teddy Roosevelt and federal legislation such as the 1906 Meat Inspection Act and Pure Food and Drug Act or the 1916 Adamson Act, which mandated an eight-hour day for Railroad workers - to the more grassroots or "small-p" progressivism of workers, immigrants, and those outside the political mainstream. It was a movement led in large part by middle-class professionals - doctors, lawyers, teachers, nurses - who despite their differences were united in a belief in progress and, this is key, a sense of optimism about the future and their ability to shape it. Much Progressive history is told in either broad, sweeping strokes or rooted in the nuts and bolts of particular reform movements such as Settlement Houses, Labor Unions, Temperance, or Women's Suffrage. For a good overview of different scholarly understandings of the Progressive period see Glenda Gilmore, Who Were the Progressives? (New York: Bedford/St. Martin's Press, 2002).

17 Gary Gerstle, "The Protean Character of American Liberalism," American Historical Review, Oct. 1994, 1043-73, 1050. Gerstle provides an outstanding overview of what he sees as a shift from the cultural policies of the Progressive Age to the more economic imperatives of New Deal reform. Ibid., I045. Regarding the aims of the movement, Gerstle writes (ibid., I049), "Two of the issues that Progressives found most perplexing were the extraordinary concentration of power and wealth in the hands of relatively small numbers of industrialists and bankers and the bewildering array and unexpected vigor of ethnic cultures among the working people." 
movement as a "discursive environment." As Ethington argues, Progressivism was "neither a discrete set of new policy goals, nor the expression of the interests of a particular social group ... [but] a reorganization of the public sphere that enabled the pursuit of interests by groups and their leaders." ${ }^{8} 8$ In the Homelands shows, I would argue, arts and craft work acted as key discursive tools in Progressive-era efforts to make immigrants and working-class Americans more at home in an increasingly industrialized and urban milieu and, by extension, to make them better American citizens. ${ }^{19}$

The Homelands shows' overt "Americanization" agenda, however, also underscores some of the less "progressive" elements of the Progressive era, namely the implicit xenophobia and racism inherent in evolutionary notions of progress, paternalistic models of citizenship, and the often extremely problematic treatment of immigrants, workers, natives and all sorts of "others" in Americanization exercises and programs. The Rochester Homelands Exhibition provides an opportunity to grapple with some of the deep contradictions inherent in this moment. By looking at the objects on display as surrogates for a diverse population, we can begin to understand what was at stake in the "correct conceptions ... of Americanization work" aimed at the city's foreign-born residents. ${ }^{20}$

But who exactly were these "foreign born"? According to internal planning documents, exhibitors included individuals from Norway, Holland, the Near East, Denmark, the Far East, Poland, Portugal, Ukraine, Belgium, Sweden, Spain, Brittany, and Italy. There were also Cosmopolitan and Jewish booths and nightly performances by Native Americans. Despite the city's large and vibrant African American community and its historic ties to abolitionism and reform (Frederick Douglass lived in Rochester from I843 to I872), there were no African Americans included in the show. While no official

${ }^{18}$ Sarah Wilson, Melting-Pot Modernism (Ithaca, NY: Cornell University Press, 2010), I 5. Phillip J. Ethington, The Public City: The Political Construction of Urban Life in San Francisco (Los Angeles: University of California Press, 2001).

19 For more on the links between citizenship and Progressivism see Louise Knight, Citizen: Jane Addams and the Struggle for Democracy (Chicago: The University of Chicago Press, 2005); and Westbrook.

20 There is a large body of work on American material-culture studies. For more on this see Daniel Miller, Material Culture and Mass Consumption (Oxford: Blackwell, 1987); Ann Smart Martin and J. Ritchie Garrison, eds., American Material Culture: The Shape of the Field (Winterthur, DE: Winterthur Museum Press, 1997); Thomas Schlereth, ed., Material Culture Studies in America (Lanham, MD: AltaMira Press, 1999). For more anthropological takes see Fred Meyers, The Empire of Things: Regimes of Value and Material Culture (Santa Fe: American Research Press, 1994); and Appadurai, The Social Life of Things. For more on the burgeoning study of "thing theory" see Bill Brown, ed., Things special issue, Critical Inquiry, Autumn 200I; and John Ploz, "Can the Sofa Speak? A Look at Thing Theory," Criticism, 47, I (Winter 2005), Article 5. 
documentation for the selection process exists, the lack of African American representation would suggest that MAG staff did not want to grapple with the thorny issue of slavery, which made identifying the homeland of origin impossible. Moreover, two of the area's largest immigrant groups, the Irish and the German, also were not included, implying, perhaps, that these groups were already fully Americanized. ${ }^{21}$ Indeed, by 1920 many among Rochester's political and economic leadership, as well the MAG board, were of German or Irish descent, suggesting that they conceived of Rochester as home. $^{22}$

Following the 1919 Red Scare, Nativist sentiment, particularly the belief in the superiority of native-born Americans, especially those of Anglo-Saxon heritage, was on the rise. The Klu Klux Klan reappeared for the first time since Reconstruction and organizations such as the Daughters of the American Revolution saw an uptick in membership. Moreover, there was widespread fear that there were direct links between unassimilated immigrants and total anarchy. For example, Raymond Cole of the National Committee for Immigrants in America (CIA) warned that an unassimilated "immigrant labor" workforce was "fertile soil for the seeds of anarchy and violent socialism" and encouraged drastic measures to assure total assimilation across the American workforce. The Homelands insistence on "correct" conceptions of Americanization was meant to counter the more coercive and even violent actions taking place against immigrants at this moment in time.

Indeed, Americanization exercises were rampant in the late nineteenth and early twentieth-century United States. They ran the gamut from efforts at total assimilation to more selective programs of integration and were deployed on both the local and the national levels. In a I9I5 speech to the Knights of Columbus, for example, Theodore Roosevelt emphatically declared that "there is no room in this country for hyphenated Americanism ... a hyphenated American is not an American at all." He continued,

${ }^{21}$ It is beyond the scope of this paper to explore changing contours of whiteness in American history. For more on this see David Rodegger, Wages of Whiteness: Race and the Making of The American Middle Class (New York; Verso, 1997); Noel Ignatiev, How the Irish Became White (New York; Rutledge, 2008); and Matthew Frye Jacobson, Barbarian Virtues: The United States Encounters Foreign Peoples at Home and Abroad, 1876-19I7 (New York: Hill and Wang, 200I); Jacobson, Whiteness of a Different Color: European Immigrants and the Alchemy of Race (Cambridge, MA: Harvard University Press, 1998).

${ }^{22}$ In his 1940 report on "The Irish in Rochester: An Historian's Perspective," Rochester History, 19, 4 (Oct. 1957), I 5-16, available at www.libraryweb.org/ rochhist/vi9_1957/ vigi4.pdf, Rochester City historian Blake McKelvey outlines in detail the assimilation of the Irish into Rochester politics and society. He concludes with the assertion that, by mid-century, the Irish "have shared too many experiences with the rest of us to retain a distinctive ethnic label ... in the case of the Irish, the long process of integration has reached fruition." 
The one absolutely certain way of bringing this nation to ruin ... would be to permit it to become a tangle of squabbling nationalities, an intricate knot of GermanAmericans, Irish-Americans, English-Americans, French-Americans, ScandinavianAmericans, or Italian-Americans, each preserving its separate nationality, each at heart feeling more sympathy with Europeans of that nationality than with the other citizens of the American Republic ... The men who do not become Americans and nothing else are hyphenated Americans; and there ought to be no room for them in this country. The man who calls himself an American citizen and who yet shows by his actions that he is primarily the citizen of a foreign land ... has no place here; and the sooner he returns to the land to which he feels his real heart-allegiance, the better it will be for every good American. ${ }^{23}$

Roosevelt's charge, to eradicate the hyphen, resonated across the land in schools and pageants aimed to "Americanize" the foreign-born. Perhaps the most famous of these was Henry Ford's English School and its "Melting Pot" graduation spectacle in Dearborn, Michigan. ${ }^{24}$ The school was mandatory for all non-native workers in the Ford Motor Company, which in I9I4 was almost 75 percent of the company's workforce. Overseen by the Reverend Samuel Marquis, the school not only taught workers English - so as to avoid injury (and thereby also increase production) on the assembly line where coordination across language groups was crucial - it also schooled them in "American ways ... and the right way to live." 25 For Ford, the "right way to live" included classes in citizenship, thrift, and deportment. For example, the in-house publication, Helpful Hints to Ford Employees, advised workers, "Employees should use plenty of soap and water in the home and upon their children bathing frequently ... The most advanced people are the cleanest." 26

Describing the success of the program, a I9I4 article in the Ford Times boasted, "ask anyone of [the graduates] what nationality he is and the reply will come quickly, 'American!' 'Polish-American' you might ask. 'No, American,' would be the answer. For they are taught in the Ford English School that the hyphen is a minus sign." ${ }_{27}$ The culminating event for students in the Ford school was the "Melting Pot" ceremony, where graduates of the

23 Theodore Roosevelt, Speech to the Knights of Columbus, New York City, I 2 Oct. I 915 ; "Roosevelt Bars the Hyphenated," New York Times, I 3 Oct. I 9 I 5 , I 516.

${ }^{24}$ For more on Ford see Stephen Meyer, The Five Dollar Day: Labor Management and Social Control in the Ford Motor Company, 1908-192I (Albany: SUNY Press, 1981); and Anne Brophy, "The Committee ... Has Stood Out against Coercion': The Reinvention of Detroit Americanization, I 91 5-193 I," Michigan Historical Review, Fall 2003 , I-39.

${ }_{25}$ Marquis quoted in Steven Watts, The People's Tycoon: Henry Ford and the American Century (New York: Alfred Knopf, 2005), 215.

${ }^{26}$ Helpful Hints to Ford Employees, Detroit, MI, 1915 , I 5.

27 "The Making of New Americans," Ford Times, Nov. 1916, I 52. 
program processed onto a grand stage dressed in their native garb, up a ramp and into a giant pot. According to the Ford Times,

Into the gaping pot they went. Then six instructors of the Ford School, with long ladles, started stirring. "Stir! Stir" urged the superintendent of the school. The six bent to greater efforts. From the pot fluttered a flag, held high, then the first of the finished product of the pot appeared, waving his hat. The crowd cheered as he mounted the edge and came down the steps on the side. Many others followed him, gathering in two groups on each side of the cauldron. In contrast to the shabby rags they wore when they were unloaded from the ship, all wore neat suits. They were American in looks. ${ }^{28}$

The melting metaphor has been present in American culture since the mideighteenth century. In his Letters from an American Farmer, for example, French settler J. Hector de Crevecoeur wrote that in America "individuals of all nations are melted into a new race of men, whose labors and posterity will one day cause great changes in the world." The concept of the melting pot itself entered popular discourse through the 1908 play by Israel Zangwill. Entitled The Melting Pot, the play was a present-day adaptation of William Shakespeare's Romeo and Juliet, set in New York City. The play's protagonist is David Quixano, a Russian Jewish immigrant, who falls in love with Vera, a fellow Russian immigrant who is Christian. Unlike Shakespeare's tragedy, however, Zangwill's play has a happy ending; the lovers are united at the end. In the final act, as David and Vera watch the sun set over the Statue of Liberty, David muses, "It is the Fires of God round His Crucible. There she lies, the great Melting-Pot - Listen! Can't you hear the roaring and the bubbling? There gapes her mouth, the harbor where a thousand mammoth feeders come from the ends of the world to pour in their human freight." ${ }^{29}$ Although melodramatic, Zangwill's reconciliation of "Jew and Gentile," as well as "Celt and Latin, Slav and Teuton, Greek and Syrian - black and yellow," suggested the possibility for immigrant success through accommodation in the New World. ${ }^{\circ}$

According to historian John Higham, early twentieth-century Americanization exercises followed one of two tracks: the total assimilation of the immigrant into American life through events such as those carried out in the Ford School, and more selective integration, or what he calls "liberal Americanization," which took "a positive interest in the immigrant's welfare" and used the idea of "immigrant gifts ... [as] a defense of the

28 Ibid., I 5 I.

29 J. Hector de Crevecoeur, Letters from an American Farmer, ed. W. P. Trent and Ludwig Lewisohn (1782) (New York: Duffeild, I904), added emphasis; Israel Zangwill, The Melting Pot (New York: Macmillan, I 909), I 84.

30 The Melting Pot, i $84-85$. 
foreign-born from nativist attack." ${ }^{1}$ The Homelands shows, with their emphasis on craft work and performance, certainly fall into the latter category. In acknowledging and even highlighting the country of origin of the foreign-born, the Rochester Homelands Show positioned the hyphen not as a minus sign or as an obstacle but, rather, as a useful tool in the Americanization process - a process which in this case was neither autonomous nor assimilated but instead grounded in the experience of individuals and their creative labor. Moreover, by stressing the role of the museum in allowing for this type of social interaction and understanding, planners underscored the role of cultural institutions in responding to the enormous social and political changes brought about by industrialization and urban growth in the early twentieth century.

At the turn of the twentieth century, Rochester followed a pattern of growth familiar to anyone who studies the period in the United States similar things were happening in other mid-sized industrial cities such as Pittsburgh, Cleveland, Buffalo, St. Louis, and Detroit, all with local variation. Located in western New York State, about halfway between Syracuse and Buffalo, on the Genesee River and adjacent to Lake Ontario, Rochester was a stop on the Erie Canal. When the eastward-bound canal opened in 1823 , the city's population and economy expanded quickly. Originally known as "the flour city," for the many flour mills on the Genesee River, by the late nineteenth century the city's moniker had changed to "flower city" for the large number of seed companies and nurseries located there. Notable local companies founded during this time included Bausch \& Lomb, Eastman Kodak, Western Union Telegraph, Gleason Works, and R. T. French Company (which made French's mustard, among other things).

The Memorial Art Gallery or MAG was founded in 1913 and its programs in many ways exemplify what sociologist Paul DiMaggio and historian Lawrence Levine have termed "the sacralization of culture" in Gilded Age America. ${ }^{32}$ As cultural critic Tony Bennett explains,

${ }^{31}$ John Higham, Strangers in the Land: Patterns of American Nativism, I860-1925 (New Brunswick: Rutgers University Press, I955) I 20-I 2 I.

${ }^{32}$ For more on cultural sacralization see Lawrence Levine, Highbrow/Lowbrow: The Emergence of Cultural Hierarchy in America (Cambridge: MA: Harvard University Press, 1988); Paul J. DiMaggio, "Cultural Entrepreneurship in Nineteenth-Century Boston," in DiMaggio, ed., Nonprofit Enterprise in the Arts (New York: Oxford University Press, 1986) 41-61; Neil Harris, Cultural Excursions (Chicago: The University of Chicago Press, 1990); Ralph Locke, "Music Lovers: Patrons and the Sacralization of Culture in America," in Ralph Locke and Cyrill A. Barr, eds., Cultivating Music in America (Berkeley: University of California Press, 1997), I 49-73. 
The emergence of the art museum was closely related to that of a wider range of institutions - history and natural science museums, dioramas and panoramas, national and, later, international exhibitions, arcades and department stores - which served as linked sites for the development and circulation of new disciplines (history, biology, art history, anthropology) and their discursive formations (the past, evolution, aesthetics, man) as well as for the development of new technologies of vision. ${ }^{33}$

New urban museums such as the MAG embraced the display ideology made famous by the Smithsonian's G. Browne Goode that "to see is to know." Indeed, the primary mandate of MAG was education through cultural uplift - particularly the uplift of the working and emerging middle classes by more affluent citizens. But MAG was also created, I would argue, to mark Rochester as a viable city, since cultural institutions such as museums and opera houses were turn-of-the-century necessities for a certain type of American civic identity. Arthur Parker, director of the neighboring Rochester Museum, made this connection explicit when he stated,

Museums are a community's ideals crystallized. They reveal to the traveler, to the citizen, to the schoolchild, what the city thinks of itself. More than that, the museum tells the degree to which a community understands its responsibility to the world of science, art, letters, civic well-being. Unimportant cities have no museums; great cities have flourishing museums. ${ }^{34}$

The history of the Memorial Art Gallery nicely encapsulates the perceived links between civic identity and museum building prevalent at the time. Created by a group of wealthy patrons in conjunction with the newly established University of Rochester as a "temple to culture," MAG was the fifty-first art museum to open in the United States between I 870 and I913. The museum had no founding collection or even an endowment. Its first accession was a donated piece of antique lace. MAG's purpose in large part was to exist as a cultural institution, but a particularly American type of cultural institution. Robert de Forest, vice president of the Metropolitan Museum of Art in New York, made this clear in his keynote speech at MAG's opening night. "American museums," he explained to the audience of founders and patrons,

in contrast to European collections, were founded for educational, altruistic, and even moralistic reasons ... What king ever thought of educating people or even giving pleasure outside his court surroundings when he assembled the treasures of art? ... It has remained for the present generation to realize the relation between art galleries and education and to bring them in their proper relation to the school and the university.

33 Tony Bennett, Birth of the Museum (New York: Routledge, 1995).

${ }^{34}$ For more on this see Boris, Art and Labor; and the "Introduction" to Jackson, Lines of Activity. 
Similarly, University of Rochester president Rush Rhees, in his conception of MAG, saw the museum as the college's "ministry to the community." 35

Community outreach activities were part of the museum's programming mission from the very start. These programs ranged from informal story hours for children to more formal collaborations and workshops with local high schools and settlement houses. Regarding the early story hours, Gertrude Herdle, who started reading to children in the upstairs galleries when she herself was just a teenager, and who ultimately succeeded her father as director of the gallery, recalled,

Many a child who attends Gallery picture-story hours will one day think his or her appreciation of art is a natural gift. But if memory harks back to the lecture room underneath the Gallery where so many art treasures are housed, it will be remembered that underneath the careful sugar coating of well-chosen words was expert instruction in art appreciation such as many adults have never been privileged to enjoy.

The gallery's bimonthly publication, the Bulletin, was full of stories chronicling collaborations between MAG and Rochester City schools and settlement houses, and the local press regularly championed the gallery's public outreach programs as well. For example, a headline from the front page of the Rochester Democrat and Chronicle in 1924 reads, "Workmen in Overalls and Young Intelligentsia Create Demand for Larger Memorial Art Gallery." The accompanying text explained,

During the noon hour dozens of workmen from factories along University Avenue come to the Gallery in overalls to spend part of their lunch time in study of the exhibitions. Their attitude toward art is one of reverence ... Spirited discussions regarding the merits of the paintings are carried on. ${ }^{36}$

The desire to create a sense of awe for the art on display and simultaneously foster spirited discussion about its merits captures the museum's founding goals to be a cultural minster to the community. By interacting with art (often loosely defined), museum personnel hoped that visitors would learn object lessons in citizenship and taste; workers would mingle with intellectuals, and both would be trained in proper deportment through their interactions in the museum's hallowed halls. Moreover, through art classes and craft displays, MAG presented a more participatory form of art appreciation, one centered not only on looking but also on doing and making. But how exactly did looking at things or people making things translate into more correct forms of Americanization? How did they teach tolerance and inspiration through

35 See Elizabeth Brayer, Magnum Opus: The Story of the Memorial Art Gallery (Rochester, NY: Memorial Art Gallery, 1988) 56.

${ }^{36}$ See ibid. 
the display of craft and weaving and furniture-making demonstrations in shows such as the Homelands Exhibition?

One of the ways that MAG staff attempted to make the work more accessible to diverse audiences was through translation. Individuals and crafts from twenty-two different countries were included in the Rochester Homelands show. Each ethnic group received their own booth and each booth had an interpreter. According to planning documents, the interpreter should be

A person with a fund of human interest stories about the objects displayed ... but care should be taken to see that the information given is authentic. The interpreter should usually be of foreign birth, which in itself would lend authenticity to exhibit for the native born, and would emphasize the contribution of the foreign born to the exhibition.

The role of the interpreter was both metaphorical and literal. On the one hand, the interpreter's job was to validate the "authenticity" of the experience: to demystify both the goods and the people on display through context and translation. On the other hand, however, the presence of the interpreter presumes that without translation the objects - and by extension the native culture and its people - were illegible; that neither the pieces nor the craftsman could speak for themselves.

The emphasis in all the booths was on the material culture of the "homelands." For the most part this consisted of handicrafts: lace, embroidery, baskets, pottery, and furniture were in abundant display. These crafts were afforded the same reverence as the fine-art objects on display in the MAG's galleries (which included similar objects). Such a curatorial strategy allowed the show's planners first to aestheticize traditional craft and then, in so doing, to legitimize it. This legitimation exercise became a way to introduce the foreign-born to the American public and in the process "Americanize" them through inclusion. By presenting a variety of lace, for example - from Ukraine, from Italy, from Spain, etc. - they visually suggested a universal language of lace. Yet by differentiating between Italian and Spanish or Ukrainian lace (often through lace-making demonstrations in each booth), they maintained the significance of different lace, and thus ethnic traditions. ${ }^{37}$ Seeing was knowing, but it was also key to understanding and ultimately behaving. Rather than erase the hyphen or see it as a national threat, the Homelands Exhibitions rooted the Americanization process in the translation and then acceptance of the hyphen as contained in the material culture, and by extension the people, from the different ethnic communities on display. Ethnic difference, and the labor that created and maintained it, became encapsulated in

37 For more on artisanal lacemaking and immigrant communities see Boris, chapter 7, "Women's Culture as Art and Philanthropy: The Revival of the Textile Arts." 
the craft objects and performances on view at the exhibition. Instead of leaving past traditions in the homeland, Progressive planners in western New York proudly brought the homelands to the museum's temporary walls.

The rules for selecting articles for inclusion in the show were "very elastic"; organizers were advised

to remember one thing often overlooked ... that objects which may not be well done or beautiful in themselves can be so placed that they will harmonize and really add to the attractiveness of the whole ... an otherwise indifferent object might add variety and picturesqueness to a group.

What objects, we might ask, did not harmonize? And how exactly were they integrated into the picturesque tableau? One way that organizers dealt with different notions of quality and beauty was to set aside special days for different nationalities so that their crafts and traditions could be viewed, even those that "because of their unattractiveness, their poor quality, or an overabundance of similar ones cannot be harmoniously worked into the exhibition." ${ }_{38}$ The objects thus became direct surrogates for the democratic process - even those not immediately recognized as beautiful or worthy of inclusion were reframed in such a way as to demonstrate their worth.

Although we can certainly see this as another example of melting-pot ideology at work, I would argue that it is perhaps more complicated and even radical for the time. Rather than integrate difference into a uniform, multi-ingredient stew, the Homelands strategy allowed for the maintenance of difference across time and space - from the various homelands to present-day Rochester. The objects and their means of creation may have been recontextualized, but ultimately they were not changed. Nor were they bracketed in a moment in the past. Echoing the cultural pluralism of Randolph Bourne, who in 1916 advocated for "a higher ideal than the melting pot" and lamented that the "distinctive qualities" of various immigrant groups had been "washed out into a tasteless, colorless fluid of uniformity," MAG planners presented a dynamic narrative of cultural integration, more attentive and even respectful to the cultural traditions of the foreign-born. ${ }^{39}$ Nevertheless, these efforts were still part of an

${ }^{38}$ See http://mag.rochester.edu/plugins/acrobat/history/homelands/DocsFromMAGArchives2. pdf.

39 Bourne, "Trans-national America," 5, pointedly continued, "Already we have too much of this insipidity, masses of people who are cultural half-breeds, neither assimilated AngloSaxons nor nationals of another culture ... Our cities are filled with these half-breeds who retain their foreign names but have lost their foreign savor ... It does not mean that they have been really Americanized. It means that letting slip from them whatever native culture they had, they have substituted for it only the most rudimentary American - the American culture of the cheap newspaper, the ' movies,' the popular song, the ubiquitous automobile ... this tame flabbiness is accepted as Americanization." 
Americanization program aimed, ultimately, at creating good disciplinary citizens. By rooting difference in lace and cloth, they domesticated it and made it less threatening to contemporary audiences.

Moreover, the Homelands' notion of "a correct conception" of Americanization, with its emphasis on material objects and their makers, was also a means of culturally integrating immigrant populations and their labor more fully into an aestheticized, and even sanitized, capitalist marketplace. While not as blatant as Ford and his fellow assimilationists in groups such as the CIA (whose goal was to produce a docile and productive labor class as well as a new class of consumers for the products being produced), events such as the Homelands Show, with its emphasis on craft objects and their production and circulation, in a sense depoliticized labor while translating both ethnic craft and craftsman into new forms of commodity.

Responding to the growth of industrial capitalism in the early nineteenth century, Raymond Williams has compellingly identified the moment in which art became a commodity form. Prior to industrialization, he argues, "An art had formerly been any skill, but now Art signified a particular group of skills, the 'imaginative or creative arts.' ... Art came to stand for a special kind of truth, 'imaginative truth,' and artist for a special kind of person." $4 \circ$ Similarly, Eileen Boris has traced how the Arts and Crafts movement in both Britain and the United States further solidified the lines between art and craft as "art was becoming a commodity, and the artist a commodity producer." As a result, she writes, "The defenders of art as a higher and more spiritual essence began to place art in opposition to labor." The craftsman emerged "as the characteristic citizen and craftsmanship as the core value ... in sharp contrast to the commercial values of the "era of big business." " 41

At first glance, the activities at the Homelands Show seem to follow Ruskin's and Morris's socialist goal of more fully integrating art and labor into daily life. But by blurring the lines between art and craft and focussing on what Appadurai calls the "exchangeability (past, present, future) [of one thing] for some other thing," the Homelands exhibits skillfully presented both craft object and craft maker as viable objects of exchange within a rapidly expanding commodity culture - simultaneously exposing and safely containing the labor that went into making the works, and the potential Americans, on display in the show. ${ }^{42}$ One of the key ways that they did this

${ }^{40}$ Raymond Williams, Culture and Society, 1780-1950 (New York: Harper and Row, 1966), xiv.

${ }^{42}$ As Appadurai, Introduction: Commodities and the Politics of Value," in Appadurai, The Social Life of Things, 3-63, 5, 13, reminds us, all things "have no meanings apart from those that human transactions, attributions, and motivations endow them with." $\mathrm{He}$ 
was through craft demonstrations in which the foreign-born produced examples of the goods on display, thus making themselves into exemplary immigrants in the process of being made into exemplary Americans.

In her essay "Objects of Ethnography," Barbara Kirshenblatt-Gimblett differentiates between what she calls in situ and in-context exhibitions. Through both metonymy and mimesis, in in situ exhibitions, she writes, "the object is a part that stands in a contiguous relation to an absent whole that may or may not be recreated." At their most mimetic, "in-situ installations include live persons, preferably actual representatives of the cultures on display." Thus live performances "create the illusion that the activities one watches are being done rather than represented, a practice that creates the illusion of authenticity or realness," and ultimately "people become signs of themselves." 43 In addition to the craft demonstrations in each booth, each day of the show featured a variety of musical events with children performing during the day and adults joining them in the evening. A sample program from I 2 April, for example, lists a "Children's Program" from 9:30 a.m. to i I:30 a.m. and again from 2 p.m. to 4 p.m. At 8 p.m. the Italian Fashion Park Band gave a short concert. That night's performance also included Lithuanian clog dancing as well as an Italian chorus performing the tarantella and a polka dance, as well as selections from Lucia de Lammermoor.

Almost every day local newspapers published images of children in native dress performing at the exhibition. Ironically, many of the children were actually born in the United States. Including them as "foreign-born" makes one wonder what exactly constituted the boundary between the "native" and the "foreign-born." While we can see this as an essentializing gesture in which certain racial and ethnic groups are marked as foreign across generations, acknowledging these children in this moment as hyphenated citizens despite their lack of physical ties to the actual "homelands" - also suggests a much more tolerant notion of ethnicity in the context of larger Americanization programs. These dances and dress were not something for future generations to forget, to leave in the melting pot, as it were. Rather, highlighting the cultural traditions of native-born children suggests that the collective past and its rich traditions were alive and even respected in the new American present and would continue to be so, for generations to come.

further proposes that "the commodity situation in the social life of any 'thing' be defined as the situation in which its exchangeability (past, present, or future) for some other thing is its socially relevant feature."

${ }^{43}$ Barbara Kirshenblatt-Gimblett, "Objects of Ethnography," in Kirshenblatt-Gimblett, Destination Culture: Tourism, Museums, and Heritage (Berkeley: University of California Press, 1998), 288-89, 409. 
The Exhibition Hall prominently featured a central stage for entertainments, "the background of which was tastefully and ingeniously arranged to represent one of Columbus' ships." Every evening there was a

short pageant depicting Columbus's arrival together with the friendly reception accorded him by the Indians. They were not mere actors but actual Redskins from a nearby Reservation. After the regular landing episode had opened the entertainment, schoolchildren would emerge from behind the sails and rigging of the ship and a give a program of dancing and singing, showing the contributions of the different homelands to music, to dance, and to physical culture in American schools.

The inclusion of "actual Redskins from a nearby Reservation" (as well as the exclusion of African Americans from the program) will no doubt read as problematic to twenty-first-century audiences (myself included), and again raises serious questions about who constituted the "native-born" as well as the original settlers. Rather than dismiss this gesture outright, however, we can see it as an attempt to afford iconic and mythic rituals of encounter to each group of "foreign-born" performers. By literally setting the stage, Native American performers assumed a key place in the national pageant. They acted as a reminder to the audience that they were the original native-born Americans as night after night they reenacted the founding story of cooperation and accommodation for each ethnic and national group that appeared on the stage, thus affording each immigrant the same access to this encounter as the earliest colonists. Moreover, by launching Columbus's ships and not the Mayflower in each performance, pageant planners shifted the founding narrative of American encounter from an Anglo-American story to one initiated by southern Europeans, thereby rewriting canonical stories of America's heroic past on a nightly basis. This performative gesture was in its own small way a subversive one at a time when nativist sentiment was on the rise and members of these same immigrant groups were often the victims of violent oppression and coercion.

If we try and take the nightly performances at their contemporary face value and focus on the metrics of evaluating their success used by the planners, not by twenty-first-century standards, we have a different measure of what constitutes successful Americanization. For example, the concluding paragraph from the Russell Sage Foundation report on the Homeland Exhibitions stated,

It is not the thing which is done that makes a work of art, it is the manner of doing it. These exhibitions of things made by unschooled but sensitive people who knew not the rules of composition and color but who felt strongly the impulse to create beautiful objects and responded to that impulse, will not only help us to appreciate more fully the folk culture of the many homelands from which America is made up, but they will give us a vision of what we may reasonably hope to see in a renaissance of all the arts in our country. Perhaps the greatest thing, however, they will do is to 
help us understand that art in its true sense, whether it be folk or fine, is the expression of joy in work. ${ }^{4}$

Such rhetoric allows us to look at the processes and the qualities they contain increased tolerance, joy in work, the hope for an artistic renaissance in the United States - without dismissing them outright for some of the larger problems ("friendly Redskins"). If we look at the actual objects on display - pieces of lace, embroidered tunics, handcrafted pottery and glassware - the question becomes, how exactly do these objects teach us these things? What exactly do they communicate to viewers - immigrant and nonimmigrant alike?

In an increasingly industrializing age, visitors to the show would have perhaps been nostalgic for the handicraft economies that produced these goods, so the works would have communicated a literal nostalgia - a homesickness, a longing for the past, for the world left behind. Following Morris and Ruskin, the exhibition valorized craftsmanship and promoted the idea that unalienated labor by its very nature was a form of art. By equating handiwork with the "Old World," planners identified a progressive historical timeline that situated the homeland both temporally and spatially elsewhere. By including demonstrations of local artisans making their ethnic/homelands goods in present-day Rochester, however, they complicated this timeline of progress and dislocation and bestowed present-day value not only on the goods, but also on the individuals who made them - both then and now, here and there.

In an interview for the Archives of American Art years later, Gertrude Herdle, MAG's second director (and the daughter of its first), shared a story about going with her father to various immigrant households to look for materials for the Rochester Homelands Show. Because many of the people they solicited were often reluctant to talk to them, they often had to have local priests act as intermediaries. And, she recalls, they "had to wait while they went down cellar or ... to some attic space to find the objects ... things that had been brought over but not revered." Twenty-five years later, Herdle "went to those same doorsteps and found, in nearly every case, that they [the objects] were now on the parlor walls" and that the people living there "were very proud of the things there." This is a powerful anecdote and underscores the success of the show as an Americanization exercise. The transformation of these goods from hidden objects to emblems of pride bespeaks a form of assimilation through aestheticization. Instead of hiding the pieces - and by extension their ethnic backgrounds - MAG staff legitimized these works as worthy objects of both art and identity. Once again, they rooted both in the experience of material culture. The things did the

${ }^{44}$ Eaton, Immigrant Gifts to American Life, 158. 
work of framing the ethnic past in the homelands and fostering a sense of belonging in the American present. ${ }^{45}$

This suspension of an overt timeline of progress is one of the more interesting aspects of the Homelands shows. Earlier models of craft display and demonstration - such as Jane Addams's Labor Museum at Hull House and those at World's Fairs and International Expos - located "ethnic" craft production as an important moment in the past within an evolutionary timeline from the distant homelands to present-day America. ${ }^{46}$ Regarding spinning and weaving demonstrations at Hull House, for example, Jane Addams explained that "women of various nationalities enjoy the work and recognition which it very properly brings them as mistresses of an old and honored craft, but the whirl of wheels recalls many a reminiscence and story of the old country." 47 But by locating a timeless value in the objects in this exhibit, as well as in its modes of production across time and space, and linking it directly to ethnicity, MAG curators bestowed intrinsic value on the present-day object and maker alike. This is a small difference, but one that I think bears consideration, especially because, in 1920 , ethnic difference could get you thrown in jail, or worse.

In order to fully understand the broader significance of the series of western New York Homelands exhibits, we need to place them more fully in the context of the 1919 Red Scare, which had its origins in the hypernationalism of World War I and the socialist Revolution in Russia. In I919, President Wilson appointed Mitchell Palmer his Attorney General. Palmer was active in Progressive Party politics and had been a staunch supporter of women's suffrage and trade union rights. Once in power, however, Palmer's views on civil rights changed dramatically. He became convinced that Communist agents were planning to overthrow the American government. His view was reinforced by the discovery on I May (May Day) of thirty-eight bombs sent to leading politicians and businessmen and by an Italian anarchist who blew himself up outside his Washington, DC home early that summer. Palmer recruited J. Edgar Hoover as his special assistant and together they used the

45 Marcus Lee Hansen's assertion, "What the son wishes to forget, the grandson wishes to remember," in his 1937 address to a group of Swedish Americans became the basis for what is now commonly referred to as Hansen's law. For more on Hansen's law see Donald Weber, "Reconsidering the Hansen Thesis: Generational Metaphors and American Ethnic Studies," American Quarterly, 43, 2 (June 1991), 320-32.

${ }^{46}$ For more on Addams see Boris and Jackson, Lines of Activity. For more on ethnographic displays at World Fairs see Robert Rydell, All the World's a Fair (Chicago: The University of Chicago Press, 1985); Bennett, Birth of the Museum, and KirshenblattGimblett.

47 Jane Addams, Democracy and Social Ethics (Cambridge, MA: Harvard University Press, 1964; first published 1902), I 37-220. See also Boris, I 32. 
Espionage Act of 1917 and the Sedition Act of the following year to launch a widespread campaign against radicals and left-wing organizations. Palmer claimed that Communist agents from Russia were planning to overthrow the American government. On 7 November 1919, the second anniversary of the Russian Revolution, over ten thousand suspected communists and anarchists were arrested - many of them immigrants. While Palmer and Hoover found no evidence of a proposed revolution, they continued to monitor, arrest, and hold large numbers of immigrants and radicals for suspected subversive activities.

As I mentioned earlier, both Rochester and Buffalo had large immigrant communities. They also had strong associations with the anarchist movement. Anarchists assassinated William McKinley in Buffalo in I90 I and Emma Goldman emigrated from Lithuania to Rochester, where she lived from I 885 to I 889 . She returned often to the city to visit her sister Helena Hochstein (whose son David, a musical prodigy, was funded by Emily Sibley Watson, one of MAG's founders and chief benefactors ${ }^{48}$ ). The Homelands Exhibitions were explicitly conceived as correctives to the excessive nativist policies of Palmer and his agents - whose first proposed raid was to be in Buffalo until a judge threw out the case. The Russell Sage Foundation's choice to locate their Homelands shows in Buffalo and Rochester was strategic, since the immigrants in these two cities were repeated targets for Palmer and his agents. Instead of interrogating or castigating these populations for their ethnic backgrounds, however, the liberal Russell Sage Foundation hoped that the shows would instead model "successful experiments for recognizing the contributions of our foreign-born citizens to American culture." The foundation considered the shows to be a direct response to "the efforts at Americanization [that] were without doubt short-sighted and ill-considered, particularly those which assumed that the immigrant had nothing to contribute, that on landing he must discard all the values precious to him in his homeland."

Rather than sublimate ethnic difference or penalize immigrants for their ties to their native lands, the shows claimed to present "a better approach [that] springs from an appreciation of what he has brought to his newly chosen country, not only the myrrh and frankincense of his tribute, but treasures in the form of beautiful skills and crafts." 49 By focussing on craft work as a type of performance, the Homelands Exhibition turned the immigrant laborers who participated into artisan actors and the visitors to the show

${ }^{48}$ The relationship between the Watsons and the Hochstein and Goldman families is a subject worthy of an article itself.

49 Eaton, 158. 
into engaged spectators who helped facilitate their transition into American citizens. In this way, the audience also became a key part of this performance of American identity; they too learned "valuable lessons" about what it meant to be an American at this moment in time.

In the end, I would argue, the Rochester Homelands show was much more than just another Progressive-era sacralization exercise. Through displays of lace and embroidery and performances of ethnic dance and craft making, the material culture and traditions of the homeland became proxies for the "foreign-born" themselves, simultaneously domesticating them (and thereby making them less threatening) and marking them as different and valuable. While we could see this as reactionary, in a time of increasingly stringent immigration policies and federal laws targeting the foreign-born, this was a pretty daring stance to take. The following year, for example, the United States government passed the Emergency Immigration Act of I 92 I, which restricted the number of immigrants admitted from any country annually to 3 percent of the number of residents from that same country already living in the United States as of the I9I0 census. The Johnson Reed Act of 1924 further restricted numbers to 2 percent. With fears of encroaching socialist and anarchist agendas, in highlighting ethnic heritage and promoting pride in difference (especially among the same eastern and southern European populations being targeted by Palmer and Hoover and the new immigration quotas) the Rochester Homelands Show provided an alternative model to more rigid notions of Americanization being carried out in the name of national security. The political leanings of those included in the show were completely evacuated from the exhibits. The foreign-born involved in the booths and demonstrations, dances, and musical performances were not depicted as the May Day bombers or as anarchist cousins, but rather as future American citizens. Moreover, by locating value in unalienated labor and joy in work the Rochester Homelands show validated immigrant labor as important, not dangerous or subversive. This, I would argue, was indeed progressive, perhaps even radical.

\section{AUTHOR BIOGRAPHY}

A. Joan Saab is Associate Professor of Art History and Visual and Cultural Studies, and Chair of the Art and Art History Department, at the University of Rochester. 